TECHNICAL TRANSACTIONS 1/2017

CZASOPISMO TECHNICZNE $1 / 2017$

CIVIL ENGINEERING

DOI: $10.4467 / 2353737$ XCT.17.007.6104

\author{
Krzysztof Stypuła \\ Tadeusz Tatara (ttatara@pk.edu.pl) \\ Institute of Structural Mechanics, Faculty of Civil Engineering, Cracow University \\ of Technology
}

\title{
VIBRATIONS OF FREE-FIELD AND BUILDING CAUSED \\ BY PASSAGES OF THE PENDOLINO TRAIN
}

DRGANIA GRUNTU I BUDYNKU

WZBUDZANE PRZEJAZDAMI POCIĄGU PENDOLINO

\begin{abstract}
The objective of the paper was to conduct dynamic measurements of free-field vibrations in three profiles and establish decay relations of propagating vibrations. The sources of vibrations were passages of the Pendolino train with dedicated speeds from 40 to $293 \mathrm{~km} / \mathrm{h}$. In each profile, soil properties tests were carried out. Based on the data for a few selected speeds of the Pendolino train's passages, the Vibration Reduction Coefficients (VRC) were determined at selected points. The paper is also focused on the analysis of vibrations of the selected one-storey masonry residential building located in the vicinity of one of the profiles and their evaluation of the harmfulness on the building structure using standard scales of dynamic influence.

Keywords: free-field vibrations, dynamic investigation, speed of passage of a train, building vibrations, harmfulness of vibrations
\end{abstract}

\section{Streszczenie}

W pracy przedstawiono wyniki analiz pomiarów drgań gruntu w trzech profilach oraz podano zależności thumienia propagujących się $\mathrm{w}$ gruncie drgań, których źródłem byly przejazdy pociągu Pendolino z dedykowanymi prędkościami 40-293 km/h. W każdym profilu określono właściwości gruntu. Na podstawie danych pomiarowych wyznaczono współczynniki redukcji drgań w wybranych punktach. W pracy przedstawiono także wyniki analiz pomierzonych drgań murowego, jednopiętrowego budynku mieszkalnego zlokalizowanego w sąsiedztwie jednego z profili pomiarowych prowadzonych pod kątem oceny ich szkodliwości na konstrukcję budynku. W ocenach wykorzystano normowe Skale Wplywów Dynamicznych.

Słowa kluczowe: wstrząsy górnicze, przekazywanie drgań z gruntu na fundament budynku, transmisja spektrów odpowiedzi 


\section{Introduction}

In countries where high-speed lines operate, free-field vibrations generated by passing trains at speeds of $250 \mathrm{~km} / \mathrm{h}$ and more are of particular concern due to the impact of vibrations on neighbouring buildings and people inside them. Confirmation of the need for research in this area can be found in Council Directive 96/48/EC of 23 July 1996 concerning the interoperability of the trans-European high-speed rail system. Annex III of the Directive, which contains the essential requirements given in section 2.6.2, concerning the protection of the environment, mentions the following: Operation of the trans-European high-speed rail system must not cause a level of ground vibrations, which is unacceptable for the immediate environment in the vicinity of the infrastructure and in a normal state of maintenance. Results of studies conducted in different countries published in (e.g. [1-3]) are not always comparable because of differences in the structures of trains and surface rail, the differences in soil conditions, and finally due to local differences of the buildings' construction receiving the vibration. Therefore, also in Poland, after purchasing the Pendolino trains, it was decided that test drives need to be performed within the test framework of vibration generated by the passing train (Fig. 1). The study refers to a portion of the vibration measurements made at the turn of November and December 2013 by accredited Laboratory of Distortion and Vibration Research within the Structural Mechanics Institute at the Cracow University of Technology.

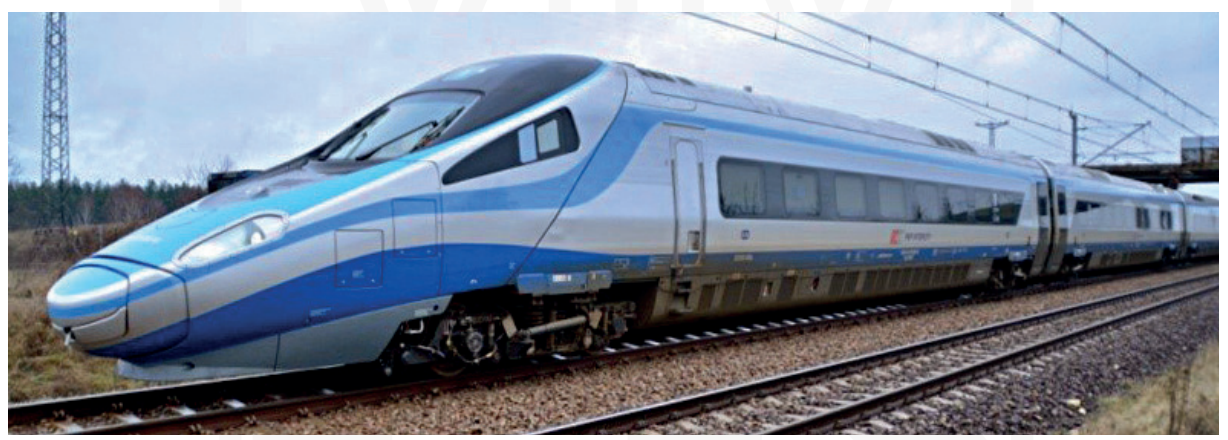

Fig. 1. The Pendolino train on the track at the site of the testing research

\section{Research of propagation of free-field vibrations}

One of the tests was to study the propagation of free-field vibration during the trial runs of the Pendolino trains on the Central Railway route (CMK) connecting the Upper Silesian Industrial Region with the Warsaw agglomeration, near the town of Przylęk located between Psary and Góra Włodowska in three selected sections of measurement. The source of vibration excitation was the passages of the Pendolino train with dedicated speeds. During the tests, acceleration of the horizontal components $(x, y)$ and the vertical component $(z)$ of free-field vibrations were measured. The direction of the $x$ is perpendicular to the railway track. Soil conditions in selected sections of the measurement were recognised before measuring free-field vibrations. Soil conditions are essential for the propagation of communication vibrations. Such vibrations depend on their 
source and the nature of the medium transferring them to the surroundings. In each measuring section, soil properties were investigated at two locations (at the foot of the railway embankment and at the distance of $20 \mathrm{~m}$ ) located adjacent to the points of measurement of free-field vibrations.

In the first section, free-field vibrations caused by 20 passages of the Pendolino running along the railway track $A$ at the dedicated speeds of $40-270 \mathrm{~km} / \mathrm{h}$ were recorded. Figure $2 \mathrm{a}$ and $2 \mathrm{~b}$ show the locations of measuring points and sensors in the first monitoring section

a)

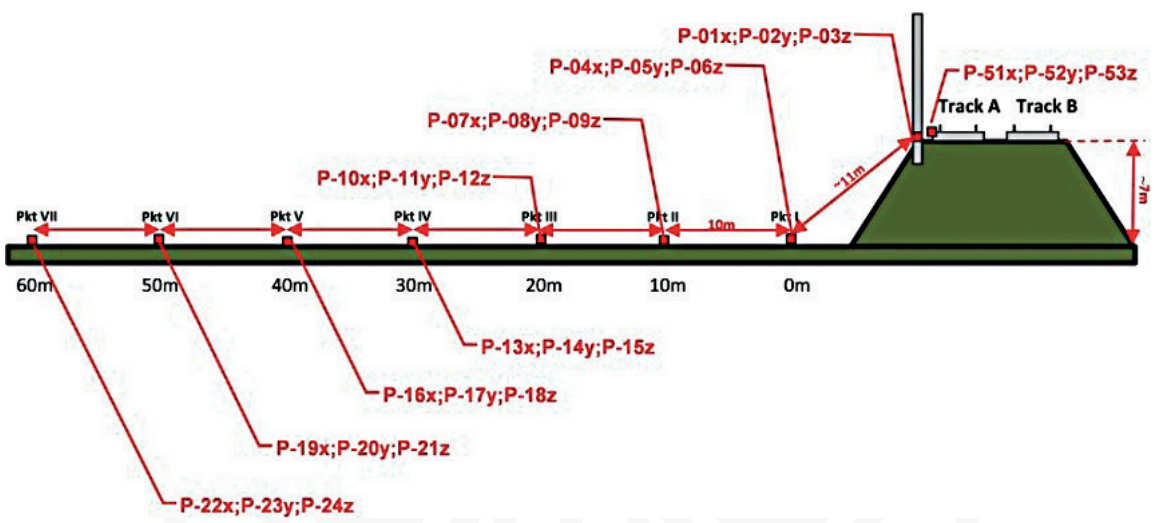

b)
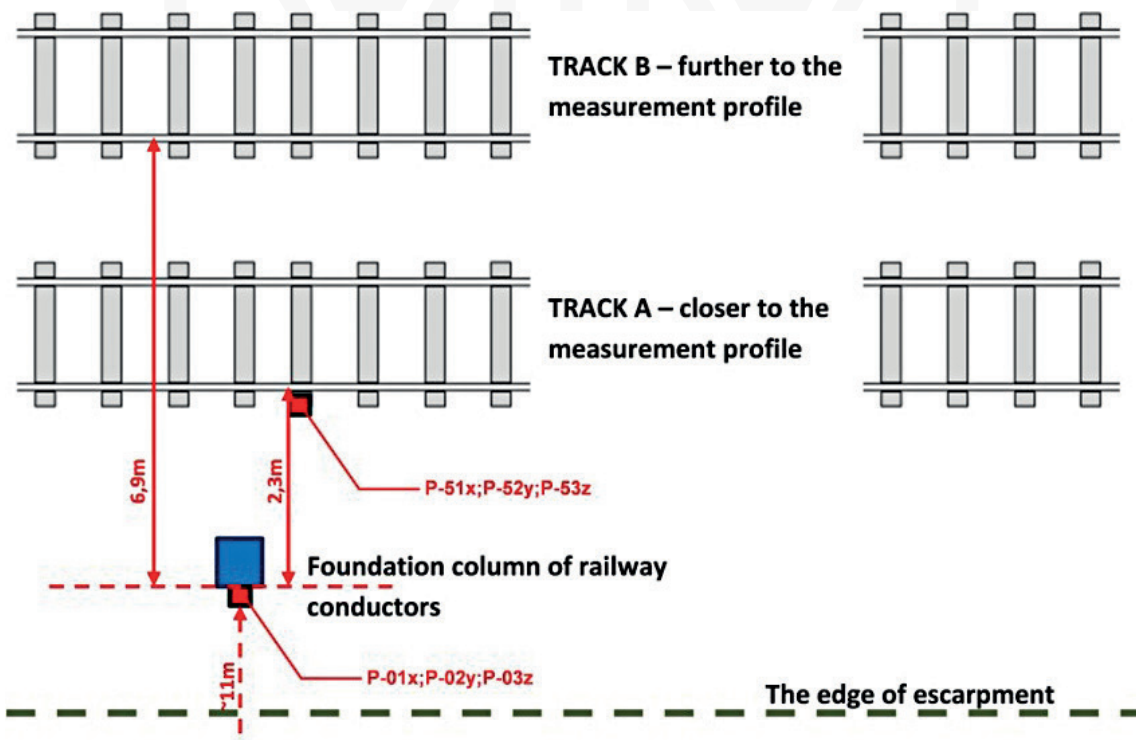

Fig. 2. Distribution of points and sensors in the first measuring profile (kilometre 177-10) on the embankment and its vicinity 
(kilometre 177-10) on the embankment and its vicinity. The measurement profile in this location is situated about $5.5 \mathrm{~m}$ below the railway track. In this section, the railway line runs along the embankment by extensive morphological reduction. In this section, the ground is layered. In the first ground profile under a thin layer of humus land is natural coarse, noncohesive sands, sandy silt changing with depth to sands with gravels. In some locations, single dusty inter-beddings were also drilled. The water level has been drilled to at a depth of $1.08 \mathrm{~m}$ below the ground surface. Medium sand layer with a dash of coarse and fine sand occurs at about $2.7 \mathrm{~m}$ below the surface in the medium-compacted state. In this profile there, is a clear vadose zone with a thickness of approx. $0.9-1.0 \mathrm{~m}$ demarcated by the underground water level; the saturation zone is located $1.4 \mathrm{~m}$ below the surface.

a)

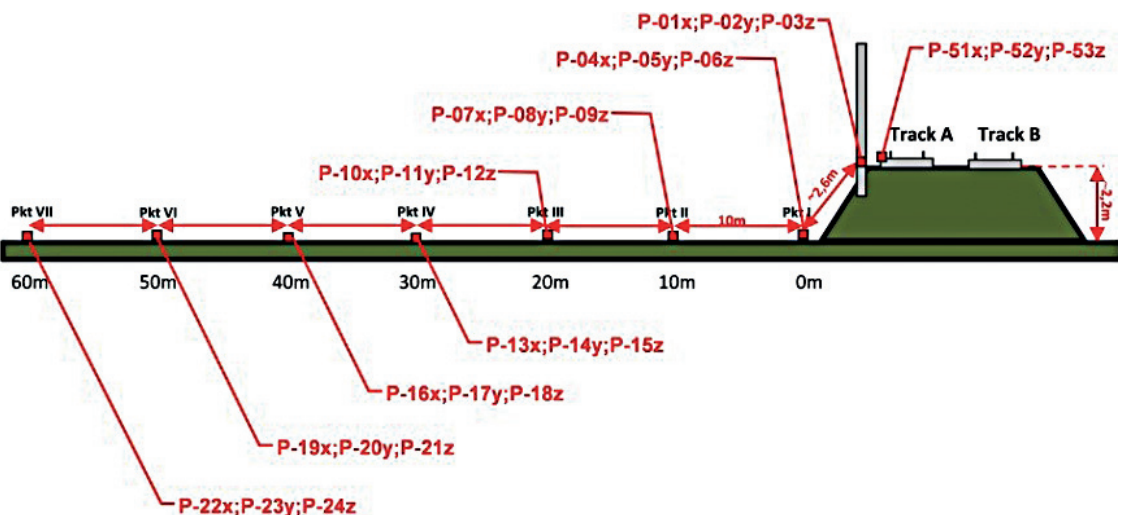

b)

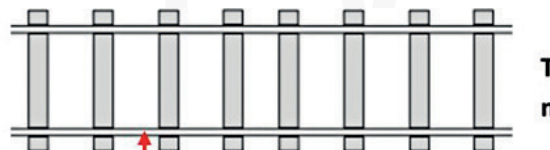

TRACK B - further to the measurement profile
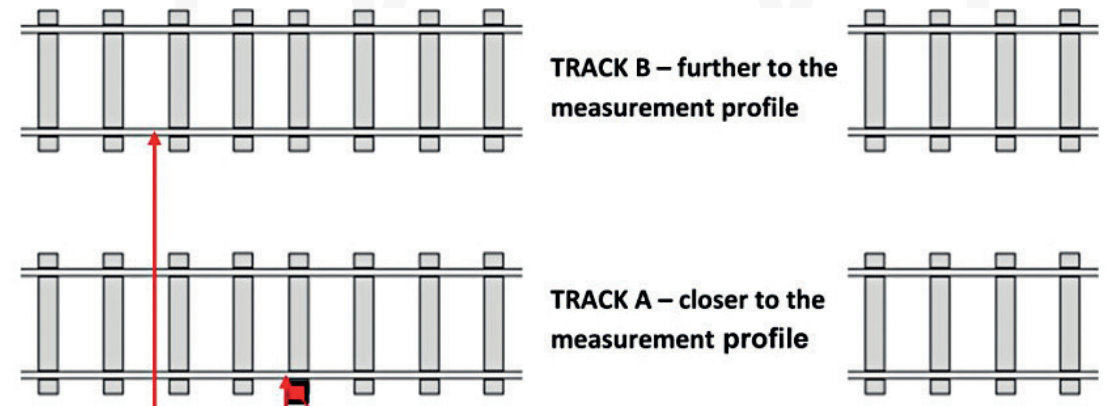

TRACK A - closer to the measurement profile
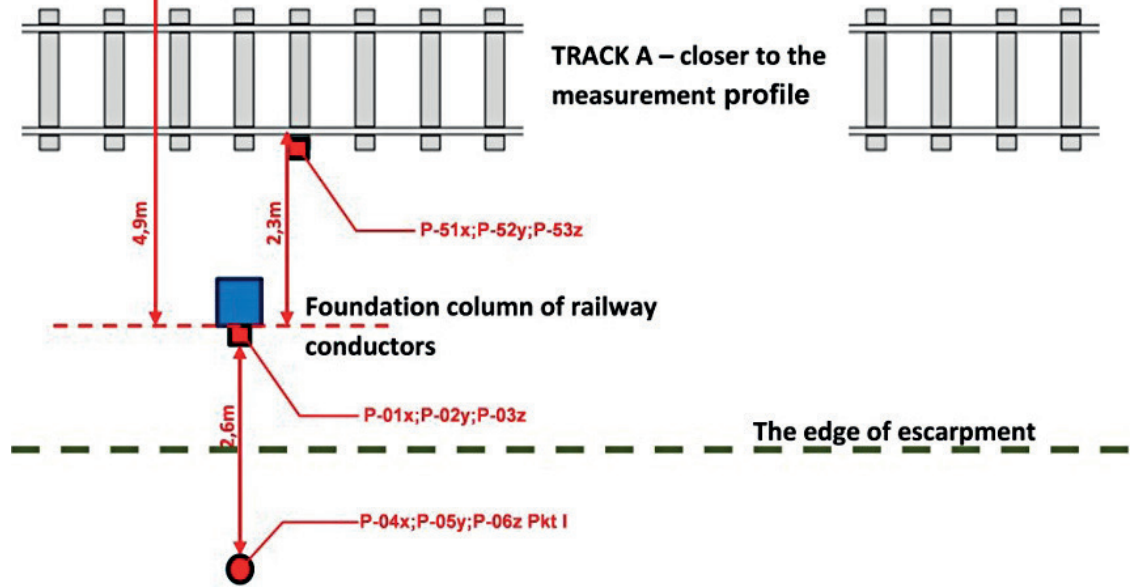

Fig. 3. Distribution of points and sensors in the second measuring profile (kilometre 180-9) on the embankment and its vicinity 
In the second section, free-field vibrations, due to 21 passages of the Pendolino running along the railway track $A$ at the dedicated speeds of $40-293 \mathrm{~km} / \mathrm{h}$, were recorded. Figure $3 \mathrm{a}$ and $3 \mathrm{~b}$ show the distribution of points and gauges in the measuring section (kilometre 180-9) on the embankment and its vicinity, respectively. Geological studies indicate that this section has a simple geological structure; the substrate is layered with a thin layer of humus and natural soils underneath. The profile is dominated by lithographic layers consisting of sandy, coarse-grained (non-cohesive) sands, medium sand with an additive of fine and coarse sand. This profile has also inter-beddings of fine-grained soils (cohesive), dust and sandy dust. Groundwater has not been drilled in this profile. Therefore, the profile is in the vadose zone.

a)

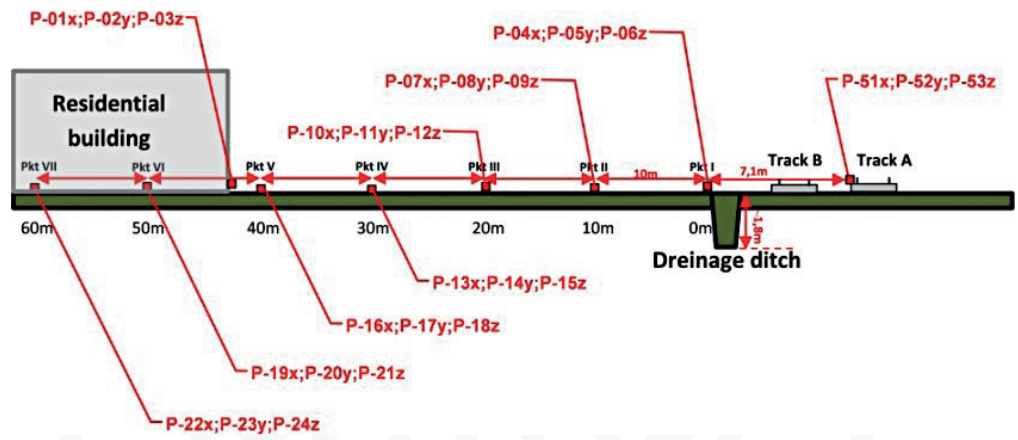

b)

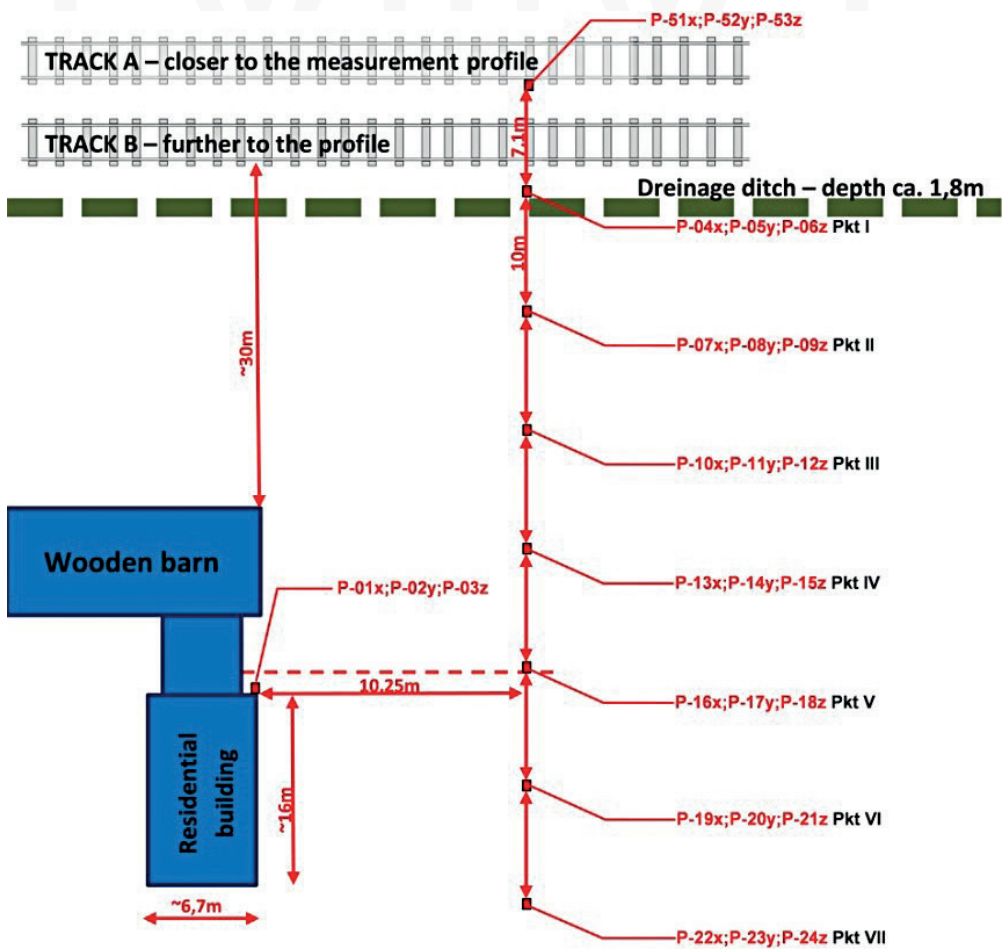

Fig. 4. Distribution of points and sensors in the second measuring profile (kilometre 180-9) on the embankment and its vicinity 
In the last, third section, free-field vibrations as well as building vibrations indicated by 27 passages of the Pendolino train running along track $\mathrm{A}$, with dedicated speeds of $40-250 \mathrm{~km} / \mathrm{h}$, were recorded. Figure $4 \mathrm{a}$ and $4 \mathrm{~b}$ show the distribution of measuring points, accelerometers in this cross section (kilometre 177-6) and on selected residential building. It should be noted that, during tests along the third measurement section, track $A$ was farther away in relation to the adopted cross-section. On the basis of geological studies, it was found that the substrate is layered. The soil profile under a thin layer of humus (approx. $0,1 \mathrm{~m}$ ) in the track area consists of a thin layer of anthropogenic soil - not buildable with a thickness of approx. $0.70 \mathrm{~m}$. Farther from the track, there are natural soils. A slab of soft rock, which consists of chalk marl, was drilled at a depth of about 0.8 meters below ground level. The maximum values of the horizontal components $x, y$, and the vertical component of the vibration acceleration caused by passage of the Pendolino train for allocated speeds in the analysed measurement sections are shown as an example in Tables 1, 2 and 3. An analysis of all measurement data showed that the highest values of the vibration acceleration of horizontal vibration components are present in the $x$-direction, i.e. perpendicular to the direction of the passages of the trains.

Table 1. Summary of maximum acceleration values of the horizontal components $x$ and $y$ and the vertical component $z, \mathrm{~cm} / \mathrm{s}^{2}$ in the profile No. 1 for selected measuring points

\begin{tabular}{|c|c|c|c|c|c|c|c|c|c|c|c|c|}
\hline \multirow{2}{*}{$\begin{array}{l}\text { Speed, } \\
\mathrm{km} / \mathrm{h}\end{array}$} & \multicolumn{3}{|c|}{ Point No. 1} & \multicolumn{3}{|c|}{ Point No. 3} & \multicolumn{3}{|c|}{ Point No. 5} & \multicolumn{3}{|c|}{ Point No. 7} \\
\hline & $\begin{array}{c}\text { P- } \\
04 x\end{array}$ & $\begin{array}{l}\text { P- } \\
05 y\end{array}$ & $\begin{array}{c}\text { P- } \\
06 z\end{array}$ & $\begin{array}{l}\text { P- } \\
10 x\end{array}$ & $\begin{array}{c}\text { P- } \\
11 y\end{array}$ & $\begin{array}{l}\text { P- } \\
12 z\end{array}$ & $\begin{array}{l}\text { P- } \\
16 x\end{array}$ & $\begin{array}{l}\text { P- } \\
17 y\end{array}$ & $\begin{array}{c}\text { P- } \\
18 z\end{array}$ & $\begin{array}{c}\text { P- } \\
22 x\end{array}$ & $\begin{array}{c}\text { P- } \\
23 y\end{array}$ & $\begin{array}{c}\text { P- } \\
24 z\end{array}$ \\
\hline 40 & 3.16 & 1.95 & 1.97 & 1.46 & 1.53 & 0.64 & 1.60 & 1.26 & 0.72 & 0.73 & 0.68 & 0.27 \\
\hline 80 & 6.20 & 3.25 & 3.59 & 2.76 & 3.06 & 1.46 & 2.41 & 2.14 & 0.99 & 1.60 & 1.20 & 0.57 \\
\hline 120 & 7.38 & 9.35 & 6.25 & 5.51 & 5.19 & 2.52 & 4.36 & 4.70 & 1.50 & 2.71 & 3.37 & 1.14 \\
\hline 135 & 13.55 & 9.27 & 7.43 & 6.81 & 6.90 & 3.12 & 6.20 & 8.16 & 2.23 & 3.69 & 3.32 & 1.23 \\
\hline 160 & 11.57 & 10.84 & 7.93 & 7.12 & 7.03 & 3.71 & 7.19 & 5.48 & 2.81 & 4.16 & 3.79 & 2.03 \\
\hline 180 & 19.13 & 9.10 & 10.36 & 9.91 & 9.41 & 3.91 & 6.08 & 7.48 & 2.57 & 4.09 & 4.54 & 2.27 \\
\hline 200 & 18.15 & 13.40 & 11.60 & 7.42 & 9.34 & 4.97 & 7.76 & 8.27 & 3.95 & 5.63 & 4.47 & 1.93 \\
\hline 220 & 13.99 & 11.50 & 10.35 & 9.31 & 9.76 & 5.91 & 9.35 & 9.09 & 3.76 & 4.33 & 5.13 & 2.66 \\
\hline 240 & 16.50 & 27.48 & 14.70 & 10.71 & 8.60 & 5.93 & 7.04 & 7.23 & 5.78 & 5.43 & 5.39 & 2.78 \\
\hline 250 & 17.52 & 16.96 & 11.35 & 9.49 & 8.66 & 5.77 & 7.75 & 7.59 & 4.99 & 5.74 & 4.30 & 2.22 \\
\hline 270 & 19.88 & 20.32 & 15.03 & 10.99 & 7.58 & 6.62 & 10.04 & 8.37 & 4.47 & 6.75 & 5.14 & 3.58 \\
\hline
\end{tabular}


A comparison of the maximum value of the horizontal components $x\left(a_{x \max }\right)$ and $y\left(a_{y \max }\right)$ listed in Tables 1-3 showed that in the overwhelming number of cases $a_{x \max }$ values were greater than the $a_{\text {ymax }}$ values. In turn, the maximum values of the vertical component $\left(a_{z \max }\right)$ were generally smaller than the maximum values of the horizontal component $a_{x \max }$. Based on the data from Tables 1-3, for some chosen speeds of the Pendolino train, passages vibration reduction coefficients were determined at selected points $(20 \mathrm{~m}$ and $60 \mathrm{~m}$ from the bottom of the escarpment). The values of the vibration reduction coefficients for each component of the vibration were calculated as the ratio of the maximum value of the measured vibration acceleration at the starting point profile to the maximum value of the measured vibration acceleration at a given distance. Table 4 and Table 5 summarise the calculated values for vibration reduction coefficients for the three components of vibration acceleration respectively 20 and $60 \mathrm{~m}$ from the bottom of the escarpment.

Table 2. Summary of maximum acceleration values of the horizontal components $x$ and $y$ and the vertical component $z, \mathrm{~cm} / \mathrm{s}^{2}$ in the profile No. 2 for selected measuring points

\begin{tabular}{|c|c|c|c|c|c|c|c|c|c|c|c|c|}
\hline \multirow{2}{*}{$\begin{array}{l}\text { Speed, } \\
\mathrm{km} / \mathrm{h}\end{array}$} & \multicolumn{3}{|c|}{ Point No. 1} & \multicolumn{3}{|c|}{ Point No. 3} & \multicolumn{3}{|c|}{ Point No. 5} & \multicolumn{3}{|c|}{ Point No. 7} \\
\hline & $\begin{array}{c}\text { P- } \\
04 x\end{array}$ & $\begin{array}{c}\text { P- } \\
\text { 05y }\end{array}$ & $\begin{array}{c}\text { P- } \\
06 z\end{array}$ & $\begin{array}{c}\text { P- } \\
10 x\end{array}$ & $\begin{array}{l}\text { P- } \\
11 y\end{array}$ & $\begin{array}{c}\text { P- } \\
12 z\end{array}$ & $\begin{array}{l}\text { P- } \\
16 x\end{array}$ & $\begin{array}{c}\text { P- } \\
17 y\end{array}$ & $\begin{array}{l}\text { P- } \\
18 z\end{array}$ & $\begin{array}{c}\text { P- } \\
22 x\end{array}$ & $\begin{array}{c}\text { P- } \\
23 y\end{array}$ & $\begin{array}{c}\text { P- } \\
24 z\end{array}$ \\
\hline 40 & 60.04 & 27.95 & 25.36 & 2.96 & 2.78 & 2.37 & 3.73 & 3.22 & 3.09 & 0.35 & 0.35 & 0.50 \\
\hline 80 & 50.41 & 25.98 & 23.49 & 3.72 & 2.01 & 2.23 & 1.44 & 1.57 & 0.98 & 0.66 & 0.43 & 0.61 \\
\hline 120 & 81.11 & 33.80 & 31.37 & 4.92 & 3.53 & 4.13 & 2.24 & 2.74 & 1.62 & 0.99 & 0.90 & 1.14 \\
\hline 160 & 68.88 & 59.59 & 48.05 & 10.74 & 6.62 & 5.80 & 5.27 & 5.74 & 2.74 & 1.34 & 0.92 & 1.28 \\
\hline 180 & 49.76 & 40.61 & 29.93 & 6.09 & 4.01 & 3.96 & 2.44 & 2.38 & 1.63 & 0.96 & 0.61 & 0.88 \\
\hline 200 & 186.10 & 134.80 & 57.94 & 9.89 & 5.45 & 7.13 & 7.27 & 8.11 & 4.62 & 1.72 & 1.52 & 2.03 \\
\hline 250 & 107.44 & 98.55 & 75.26 & 18.92 & 12.25 & 7.31 & 9.29 & 5.42 & 5.09 & 2.36 & 2.03 & 2.22 \\
\hline 260 & 195.98 & 128.91 & 62.79 & 14.58 & 7.46 & 8.38 & 8.17 & 6.42 & 4.99 & 2.36 & 2.36 & 2.69 \\
\hline 270 & 179.32 & 123.43 & 79.55 & 22.50 & 13.54 & 9.02 & 8.16 & 7.45 & 6.74 & 3.23 & 2.45 & 3.12 \\
\hline 275 & 236.96 & 117.71 & 88.30 & 12.42 & 9.50 & 8.74 & 7.15 & 7.40 & 6.29 & 3.41 & 2.39 & 4.20 \\
\hline 280 & 172.81 & 119.20 & 69.20 & 21.93 & 16.58 & 8.38 & 8.82 & 7.69 & 6.68 & 3.15 & 2.13 & 2.87 \\
\hline 293 & 241.50 & 114.38 & 87.39 & 13.24 & 7.49 & 9.01 & 6.93 & 6.95 & 6.19 & 3.67 & 2.23 & 2.88 \\
\hline
\end{tabular}


Table 3. Summary of maximum acceleration values of the horizontal components $x$ and $y$ and the vertical component $z, \mathrm{~cm} / \mathrm{s}^{2}$ in the profile No. 3 for selected measuring points

\begin{tabular}{|c|c|c|c|c|c|c|c|c|c|c|c|c|}
\hline \multirow{2}{*}{$\begin{array}{l}\text { Speed, } \\
\mathrm{km} / \mathrm{h}\end{array}$} & \multicolumn{3}{|c|}{ Point No. 1} & \multicolumn{3}{|c|}{ Point No. 3} & \multicolumn{3}{|c|}{ Point No. 5} & \multicolumn{3}{|c|}{ Point No. 7} \\
\hline & $\begin{array}{l}\text { P- } \\
04 x\end{array}$ & $\begin{array}{c}\text { P- } \\
05 y\end{array}$ & $\begin{array}{c}\text { P- } \\
06 z\end{array}$ & $\begin{array}{c}\text { P- } \\
10 x\end{array}$ & $\begin{array}{c}\text { P- } \\
11 y\end{array}$ & $\begin{array}{l}\text { P- } \\
12 z\end{array}$ & $\begin{array}{c}\text { P- } \\
16 x\end{array}$ & $\begin{array}{l}\text { P- } \\
17 y\end{array}$ & $\begin{array}{l}\text { P- } \\
18 z\end{array}$ & $\begin{array}{c}\text { P- } \\
22 x\end{array}$ & $\begin{array}{c}\text { P- } \\
23 y\end{array}$ & $\begin{array}{c}\text { P- } \\
24 z\end{array}$ \\
\hline 40 & 46.67 & 29.73 & 14.36 & 0.87 & 0.56 & 0.58 & 0.33 & 0.41 & 0.25 & 0.43 & 0.49 & 0.20 \\
\hline 80 & 84.07 & 39.02 & 16.70 & 1.35 & 1.02 & 1.78 & 1.13 & 1.16 & 0.64 & 0.72 & 0.63 & 0.36 \\
\hline 120 & 153.07 & 56.55 & 33.33 & 1.79 & 1.66 & 1.96 & 0.77 & 0.70 & 0.70 & 0.96 & 1.06 & 0.51 \\
\hline 160 & 262.22 & 137.42 & 43.22 & 2.47 & 2.66 & 1.76 & 1.30 & 1.48 & 1.23 & 1.62 & 1.83 & 0.94 \\
\hline 180 & 177.03 & 134.06 & 36.08 & 2.90 & 2.42 & 2.03 & 1.35 & 1.59 & 1.92 & 2.84 & 2.26 & 1.01 \\
\hline 200 & 187.08 & 86.43 & 39.99 & 3.56 & 5.24 & 2.77 & 1.39 & 2.81 & 1.97 & 2.68 & 2.36 & 1.14 \\
\hline 230 & 235.29 & 108.71 & 54.46 & 5.33 & 4.19 & 3.37 & 1.85 & 3.26 & 2.10 & 2.83 & 2.79 & 1.71 \\
\hline 250 & 182.39 & 113.26 & 52.58 & 25.09 & 25.90 & 24.14 & 1.85 & 3.25 & 2.15 & 3.28 & 2.76 & 1.73 \\
\hline
\end{tabular}

Table 4. The values of the vibration reduction coefficient 20 meters from the starting point of the measuring profile

\begin{tabular}{|c|c|c|c|c|c|c|c|c|c|}
\hline \multirow{2}{*}{$\begin{array}{c}\text { Speed, } \\
\mathrm{km} / \mathrm{h}\end{array}$} & \multicolumn{3}{|c|}{ Profile No. 1 } & \multicolumn{3}{c|}{ Profile No. 2 } & \multicolumn{3}{c|}{ Profile No. 3 } \\
\cline { 2 - 10 } & $x$ & $y$ & $z$ & $x$ & $y$ & $z$ & $x$ & $y$ & $z$ \\
\hline 160 & 1.6 & 1.5 & 2.1 & 6.4 & 9.0 & 8.3 & 106.2 & 51.6 & 24.6 \\
\hline 250 & 1.8 & 2.0 & 2.0 & 5.7 & 8.0 & 10.3 & 7.3 & 4.4 & 2.2 \\
\hline 270 & 1.8 & 2.7 & 2.3 & 8.0 & 9.0 & 8.8 & - & - & - \\
\hline 293 & - & - & - & 18.2 & 15.3 & 9.7 & - & - & - \\
\hline
\end{tabular}

Table 5. The values of the vibration reduction coefficient 60 meters from the starting point of the measuring profile

\begin{tabular}{|c|c|c|c|c|c|c|c|c|c|}
\hline \multirow{2}{*}{$\begin{array}{c}\text { Speed, } \\
\mathrm{km} / \mathrm{h}\end{array}$} & \multicolumn{3}{|c|}{ Profile No. 1 } & \multicolumn{3}{c|}{ Profile No.2 } & \multicolumn{3}{c|}{ Profile No. 3} \\
\cline { 2 - 10 } & $x$ & $y$ & $z$ & $x$ & $y$ & $z$ & $x$ & $y$ & $z$ \\
\hline 160 & 2.8 & 2.9 & 3.9 & 51.4 & 64.2 & 37.5 & 161.9 & 75.1 & 46.0 \\
\hline 250 & 3.1 & 3.9 & 5.1 & 45.5 & 48.5 & 33.9 & 55.6 & 41.0 & 30.4 \\
\hline 270 & 2.9 & 4.0 & 4.2 & 55.5 & 50.4 & 25.5 & - & - & - \\
\hline 293 & - & - & - & 65.8 & 51.3 & 22.5 & - & - & - \\
\hline
\end{tabular}


The analysis of the data given in Tables 1-3 and values of reduction coefficients of maximum components of vibration acceleration (see Tables 4 and 5) revealed a decrease of the maximum values of $a_{x \max }, a_{y \max }$ and $a_{z \max }$ with the distance. A significant effect of soil conditions on the values of the vibration reduction coefficients was also noted. Considerably lower values of vibration reduction coefficient were obtained in case of all three considered directions at hydrated profile No. 1. For example Figure 5, 6 and 7 show the change of the maximum value of the horizontal component $x$ ground vibrations, respectively in the profile 1, 2 and 3 for some passages of the Pendolino train with dedicated speeds.

Figures 5-7 also show the exponential dependences of the maximum value of the horizontal component $x$ of ground acceleration versus the speed of the Pendolino train, trend lines and correlation coefficients $\mathrm{R}^{2}$. An analysis of the dependences presented in Figures 5-7 showed that the maximum values of the horizontal component $(x)$ of ground vibrations across all measurement profiles decrease with increasing distance from the source of vibration. Similar results were obtained for the horizontal component $(y)$ and the vertical component $(z)$ of vibration acceleration. For example, correlation coefficient $\mathrm{R}^{2}$ for the

a)

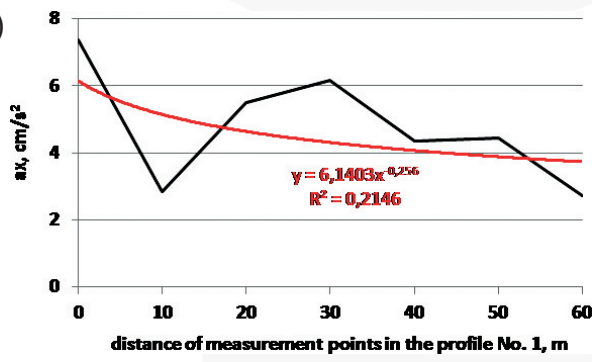

c)

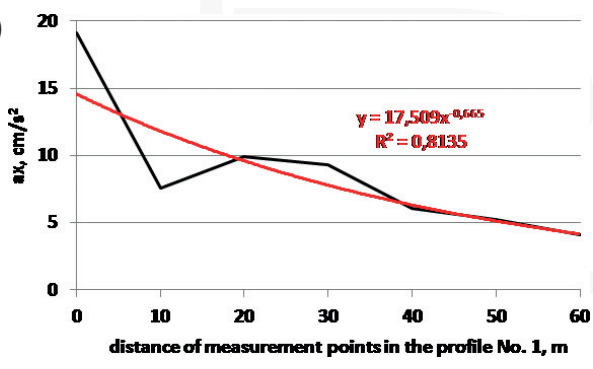

e)

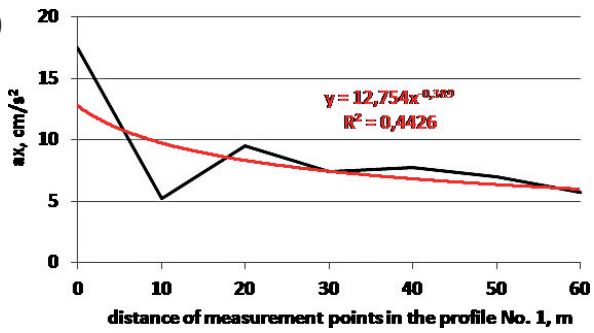

b)

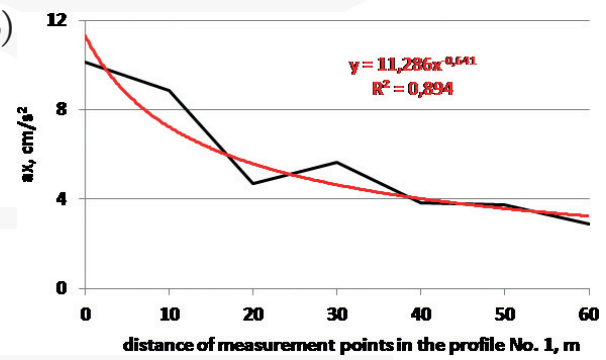

d)

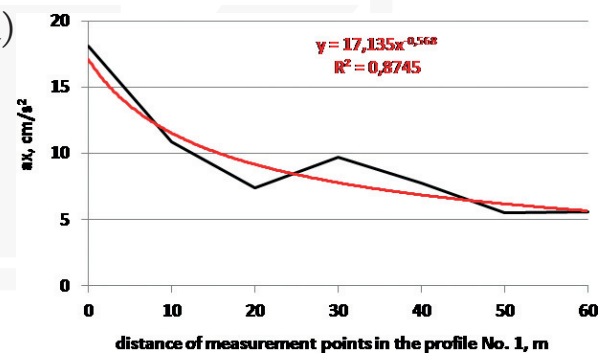

f)

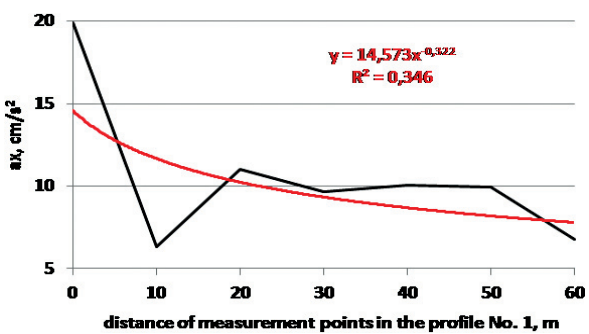

Fig. 5. The maximum value of the horizontal component $(x)$ of free-field acceleration versus the change of distance - profile No. 1, the speed of a train: a) $v=120 \mathrm{~km} / \mathrm{h}, \mathrm{b}) v=160 \mathrm{~km} / \mathrm{h}, \mathrm{c}) v=180 \mathrm{~km} / \mathrm{h}$, d) $v=200 \mathrm{~km} / \mathrm{h}, \mathrm{e}) v=250 \mathrm{~km} / \mathrm{h}, \mathrm{f}) v=270 \mathrm{~km} / \mathrm{h}$ 
exponential function between the maximum values of ground acceleration vibrations and distances from the vibration source in profile No. 2 were between $0.95-0.99$. Slightly smaller values of $\mathrm{R}^{2}$ appeared in the measuring profile No. 3 (0.84-0.895), which may be the result of the profile shape (occurrence of a drainage ditch). In profile No. 1, passages of the Pendolino train at speeds of 120,250 and $270 \mathrm{~km} / \mathrm{h}$ caused low values of coefficient $\mathrm{R}^{2}$, respectively $0.21,0.44$ and 0.35 - cf. Figure 5a, e and f. It can be associated with retention of the ground water at a very low level and rehydration of the substrate.

a)

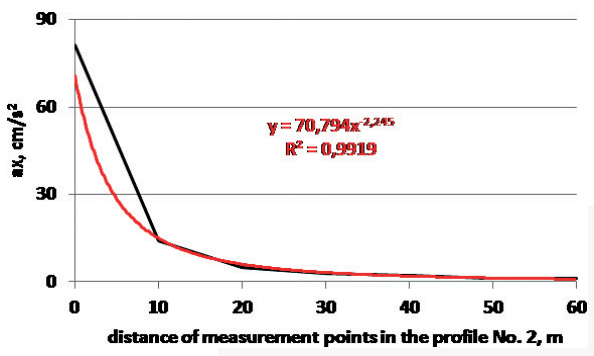

c)

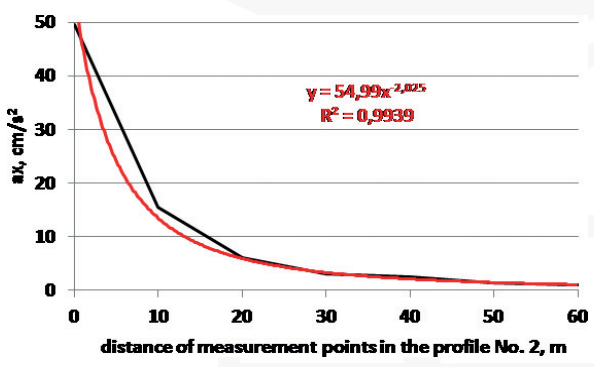

e)

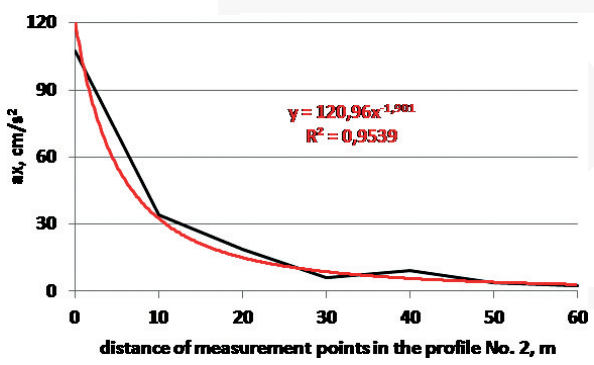

g) b)

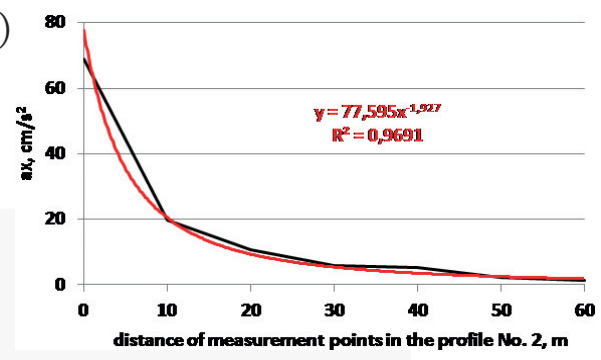

d)

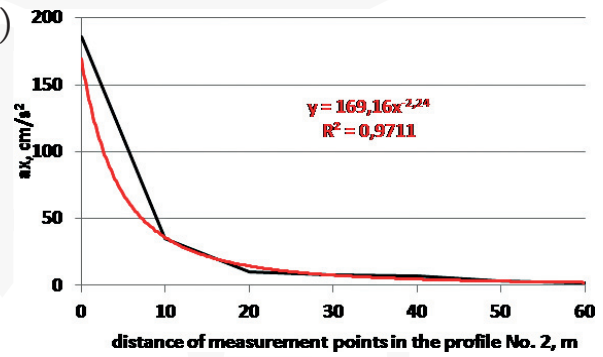

f)

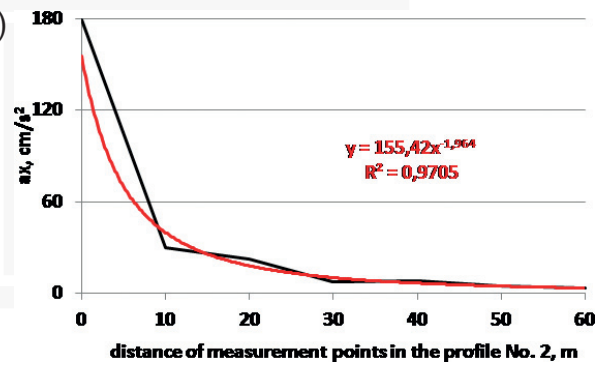

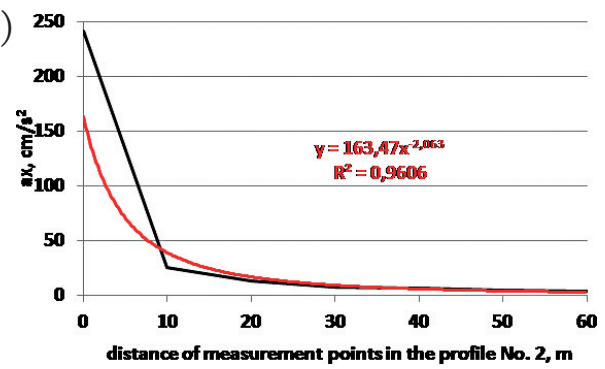

Fig. 6. The maximum value of the horizontal component $(x)$ of free-field acceleration versus the change of distance - profile No. 2, the speed of a train: a) $v=120 \mathrm{~km} / \mathrm{h}, \mathrm{b}) v=160 \mathrm{~km} / \mathrm{h}, \mathrm{c}) v=180 \mathrm{~km} / \mathrm{h}$, d) $v=200 \mathrm{~km} / \mathrm{h}, \mathrm{e}) v=250 \mathrm{~km} / \mathrm{h}, \mathrm{f}$ ) $v=270 \mathrm{~km} / \mathrm{h}, \mathrm{g}) v=293 \mathrm{~km} / \mathrm{h}$ 
a)

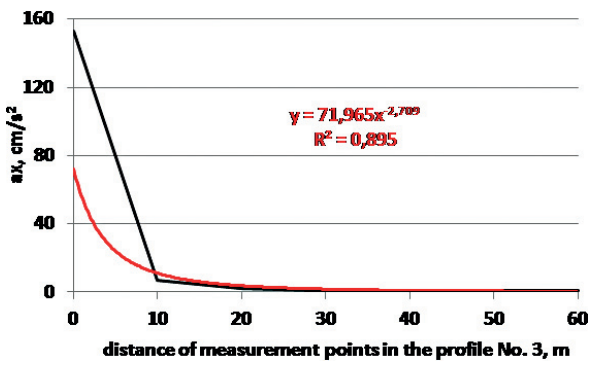

c)

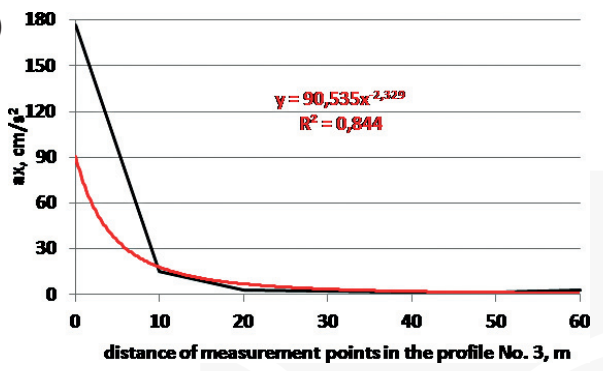

b)

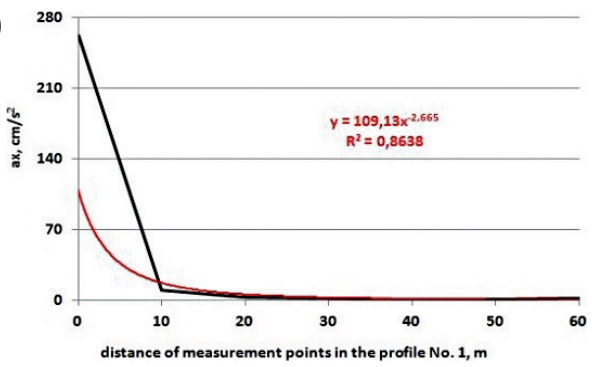

d)

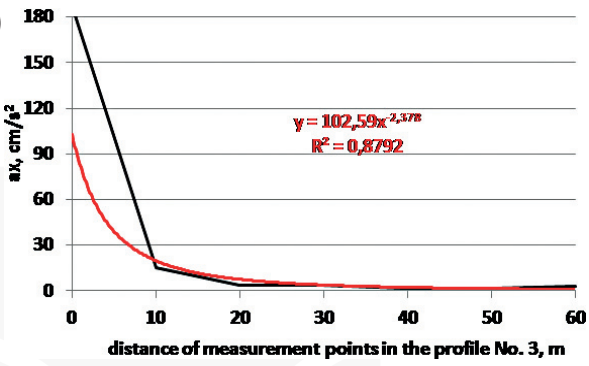

e)

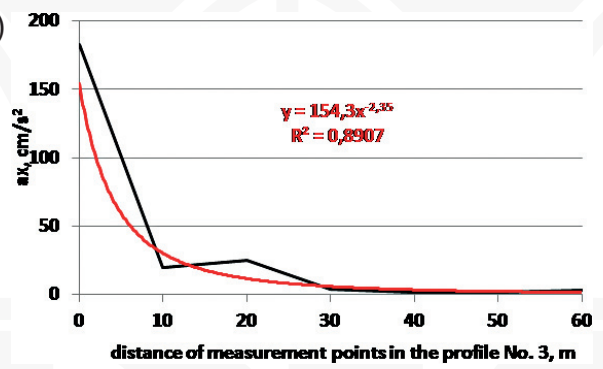

Fig. 7. The maximum value of the horizontal component $(x)$ of free-field acceleration versus the change of istance - profile No. 3, the speed of a train: a) $v=120 \mathrm{~km} / \mathrm{h}, \mathrm{b}) v=160 \mathrm{~km} / \mathrm{h}, \mathrm{c}) v=180 \mathrm{~km} / \mathrm{h}$, d) $v=200 \mathrm{~km} / \mathrm{h}, \mathrm{e}) v=250 \mathrm{~km} / \mathrm{h}$

Using measurement data contained in Tables 1-3, an attempt to determine the relationship between the maximum values of horizontal and vertical components of free-field vibrations and the speed of the Pendolino passages was made. For example, Figures $8 \mathrm{a}-\mathrm{g}$ show the change in the value of the horizontal $(x)$ component of freefield vibration acceleration in profile No. 3 as a function of the Pendolino train speeds. Figures $8 \mathrm{a}-\mathrm{g}$ also show a trend-line of the proposed function of maximum values of the horizontal $x$ component of free-field vibrations as a function of the Pendolino train speeds and correlation coefficient $\mathrm{R}^{2}$. Depending on the analysis presented in Figures $8 \mathrm{a}-\mathrm{g}$, it follows that the maximum values of the horizontal $(x)$ component of free-field vibrations rose with an increase of the Pendolino train speeds. Similar dependencies were obtained for the horizontal component $(y)$ and vertical $(z)$ of free-field vibrations. For example, the correlation coefficient $\mathrm{R}^{2}$ values for the proposed relationship between the maximum values of free-field vibrations in the profile No. 3 (measurement points No. 1-7), and the speed of passages, range from $0.47-0.96$ - cf. Figures $8 \mathrm{a}-\mathrm{g}$. An analysis 
of the data contained in Tables 1-3 implies that the relationships between maximum values of free-field vibrations and the Pendolino train speeds are variable. In most of the measuring points in the assumed measurement profiles, there is a linear trend of increasing maximum values of free-field vibrations together with the Pendolino train speeds.

a)

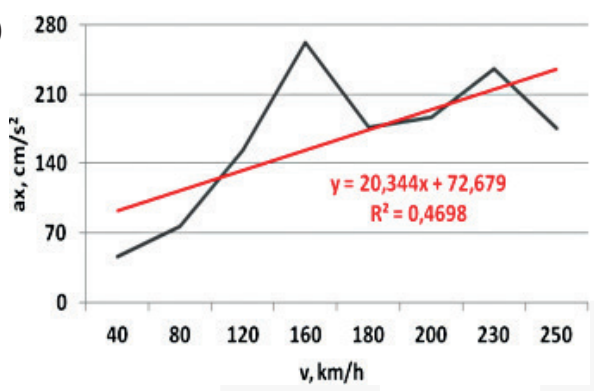

c)

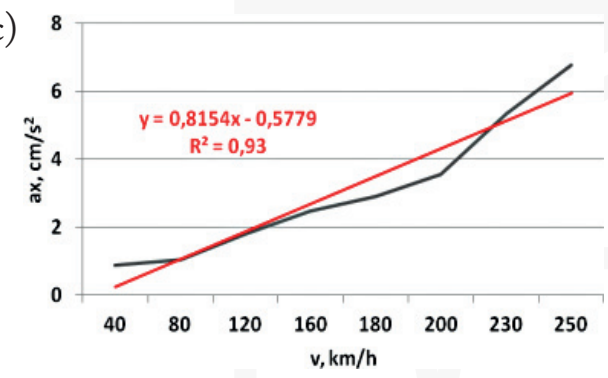

e)

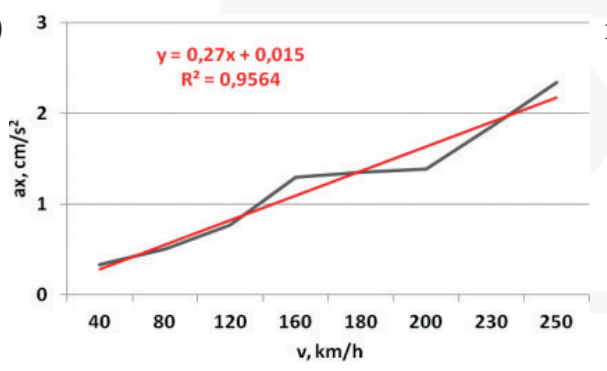

b)

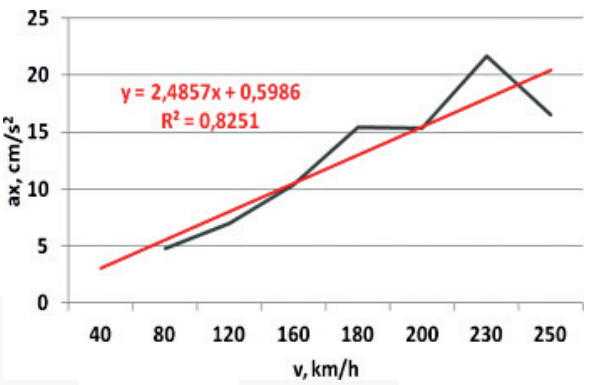

d)

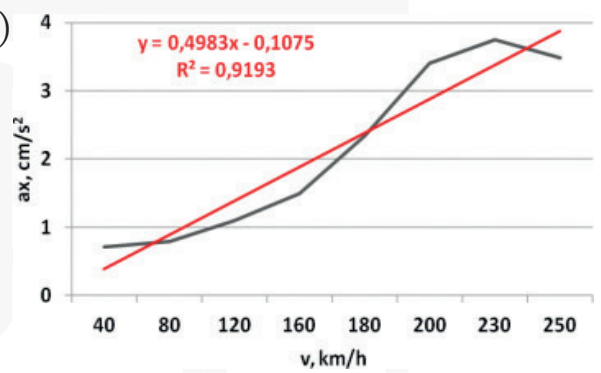

f)

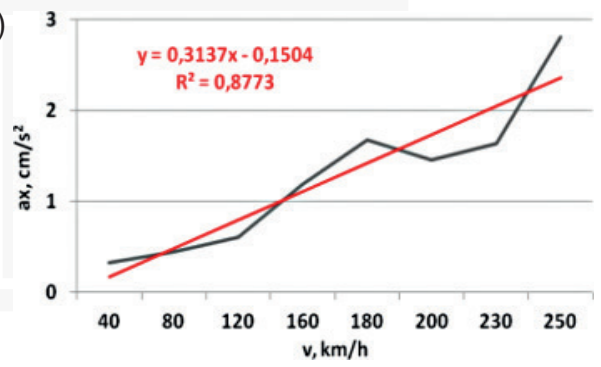

g)

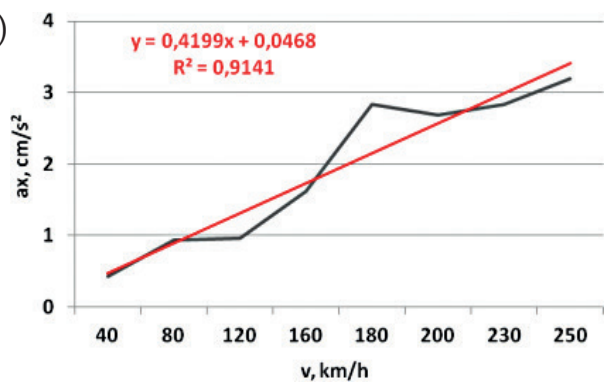

Fig. 8. Change the value of the horizontal component $(x)$ of free-field acceleration in a) p. 1, b) p. 2, c) p. 3, d) p. 4, e) p. 5, f) p. 6, g) p. 7, profile No. 3 as a function of the Pendolino speeds 


\section{Research of the vibration of the selected building}

The second part of the dynamic investigation refers to measuring the vibration of the dwelling building, situated at a distance of $49 \mathrm{~m}$ from the track along which the train was moving. The place where the study was conducted is a flat area where classical bedding layer is arranged. The investigated building is a low-rise, one-family, one-storey, masonry dwelling house with plan dimensions of $6.7 \mathrm{mx} 16.0 \mathrm{~m}$. Building vibration acceleration was measured at a ground level in order to determine the kinematic loads to which the building is subjected when the trains are passing near the building. The kinematic loads are also usable for evaluating the impact of these vibrations on the building structure using SWD scales from the Polish standard [4].

Figures 10 to 11 show an example of building vibrations due to the Pendolino passages at a speed equal to $250 \mathrm{~km} / \mathrm{h}$.

The most adverse results of the influence analysis of the horizontal components of vibration on the building during the passage of the Pendolino train at a speed of $250 \mathrm{~km} / \mathrm{h}$ are given in Figure 12a and 12b. The presented results indicate that the measured vibrations of the building are classified as non-appreciable for its construction because the peak values of vibration accelerations in all $1 / 3$ octave frequency bands are below the bottom of the curve that determines the appreciable threshold of vibrations through the structure of the building (according to the SWD-II scale from PN-85/B-02170 standard [4]).

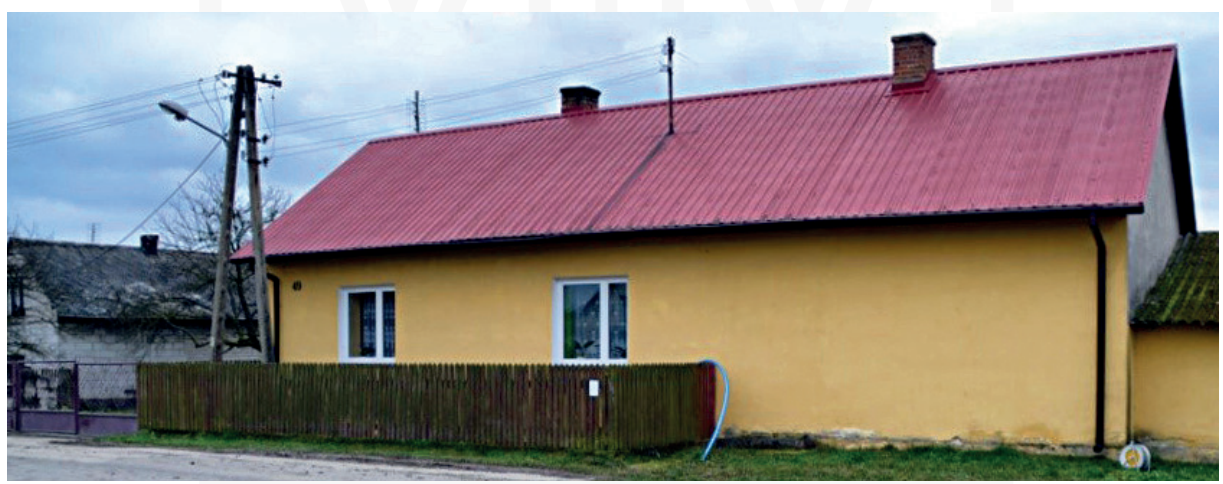

Fig. 9. View of the investigated building

a)

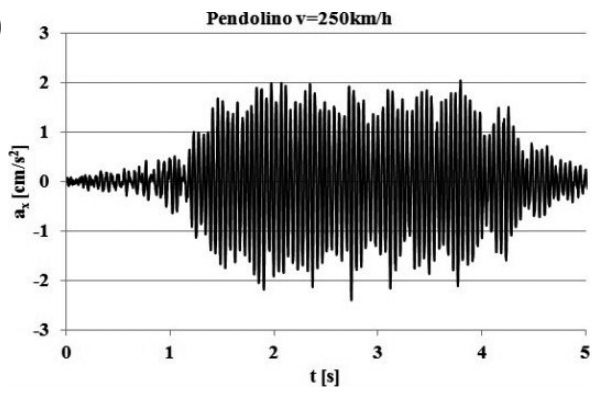

b)

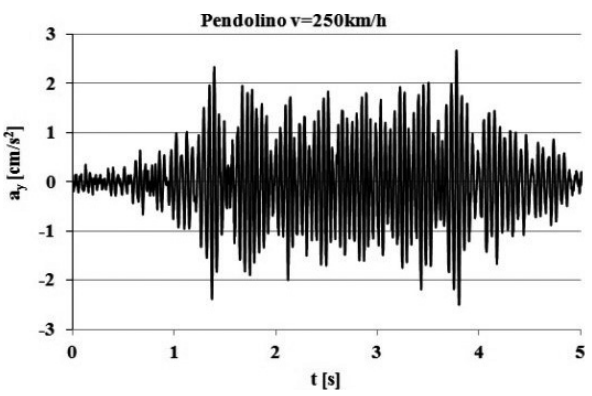

Fig. 10. The horizontal components of the vibration of the building at ground level recorded during the Pendolino passage at a speed of $250 \mathrm{~km} / \mathrm{h}$ : a) component $x, \mathrm{~b}$ ) component $y$ 
For the comparison, Figure $13 \mathrm{a}$ and $13 \mathrm{~b}$ show the results of the analysis of the impact of horizontal components $(x, y)$ of vibrations for the building caused by passenger train with a speed of $160 \mathrm{~km} / \mathrm{h}$. The level of impact of these vibrations is not appreciable for the structure of the building and is about three times lower in relation to the listed in Figure $12 \mathrm{a}$ and $12 \mathrm{~b}$, which concerns the results of the analysis of the vibration impact on building generated by passage of the Pendolino train with a speed of $250 \mathrm{~km} / \mathrm{h}$.

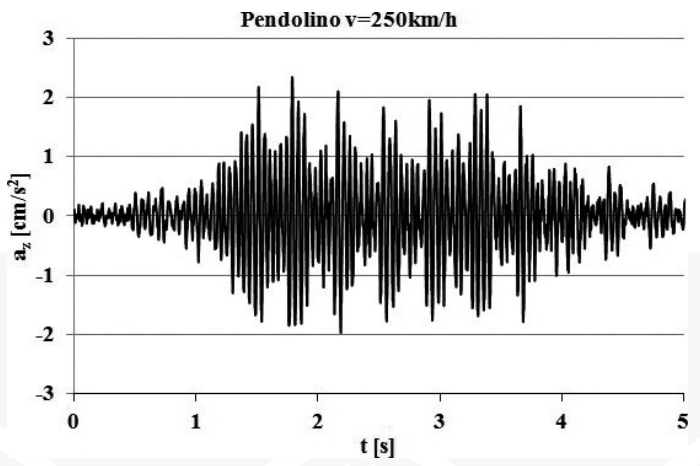

Fig. 11. The vertical $z$ component of the vibration of the building at ground level recorded during the Pendolino passage at a speed of $250 \mathrm{~km} / \mathrm{h}$

a)

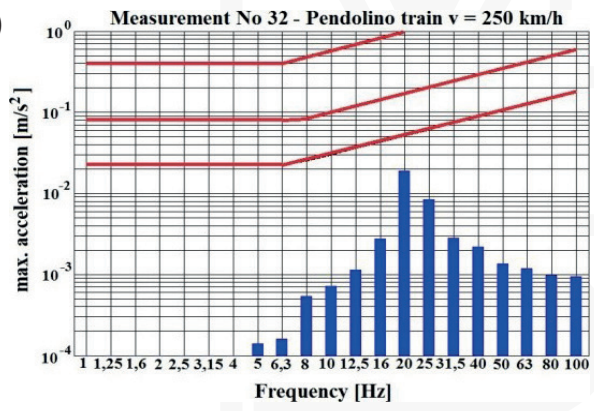

b)

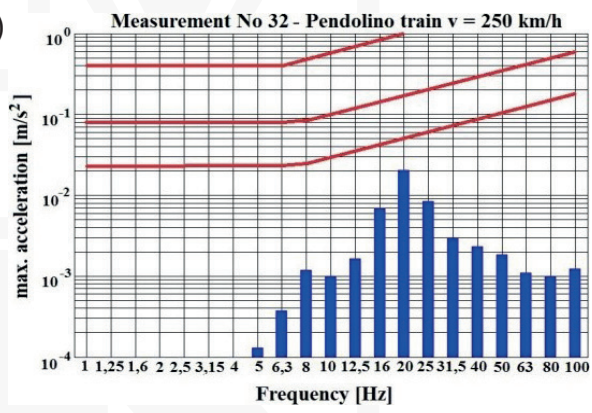

Fig. 12. The most adverse results of influence of vibrations caused by passing of the Pendolino train on the masonry structure of the building: a) component $x, \mathrm{~b}$ ) component $y$ (measurement No. 32 - 30.11.2013)

a)

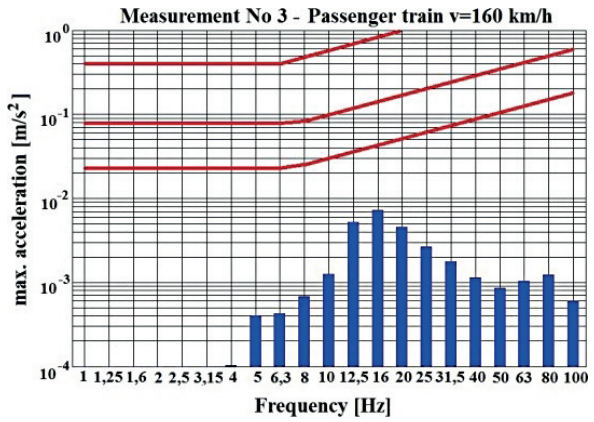

b)

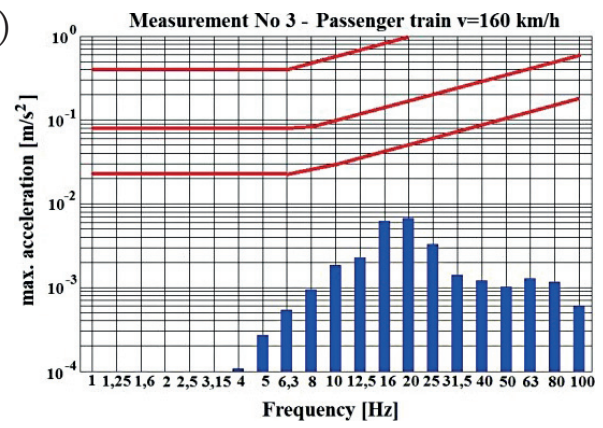

Fig. 13. The most adverse results of influence of vibrations caused by passing of the passenger train on the masonry structure of the building: a) component $x, \mathrm{~b}$ ) component $y$ (measurement No. $32-30.11 .2013$.) 


\section{Conclusions}

When drawing conclusions from the research results presented above, it should be remembered that they relate to the specific water - soil conditions in place where the vibrations were recorded and the particular type of building structure receiving vibrations.

On the basis of measurements of free-field vibrations, in three selected profiles of measurement, caused by passages of the Pendolino train and the results of the analysis of these vibrations, a relationship between the maximum values of the components of the vibration acceleration and the speed of the train can be noticed.

In the individual measuring points, generally the greater the speed of the train, the higher the value of the maximum acceleration values; there is also the impact of ground conditions on the propagation of vibrations. On the basis of an analysis of the measurement data, the exponential decay functions of maximum horizontal ( $x$ and $y$ ), and the vertical $(z)$ component of the free-field measuring vibrations in three profiles versus dedicated speeds of the Pendolino train were adopted.

Vibrations of the building generated by passages of the Pendolino train are classified as non-appreciable for the structure of the building. The reason for this is e.g. the distance of the building from the railway track. The influence of vibrations on the building due to the passages of the Pendolino train was three times higher than during the passages of trains with conventional speed.

These conclusions cannot be generalised uncritically because they concern the specific surface as well as soil - water conditions at the profile of the measurements. However, they indicate that, in the future, vibrations of buildings (and hence the people in the buildings) caused by passages of the Pendolino trains may have a higher influence than it had during conventional train crossings. Hence, the result is the need to expand the area of research of dynamic influences of the high-speed line. It is therefore necessary to elaborate and implement a comprehensive research program referring to the measurement of building vibrations generated by passages of high-speed trains, including buildings at a smaller distances than permitted by the Railway Regulations. These studies should also address the impact of vibrations on humans; account should be taken of the different types of buildings as well as various geotechnical conditions on the road of the propagation of vibrations.

The results of such comprehensive research (performed on selected profiles) should be the basis for the elaboration of environmental impact assessments and design work associated with high-speed railway program in Poland in terms of influence of vibrations on the environment and design concerning vibro-isolation.

\section{References}

[1] Madshus C., Bessason B., Harvik L., Prediction model for low frequency vibration from high speed railways on soft ground, Journal of Sound and Vibration, Vol. 193(1), 1996, 195-203. 
[2] Metrikine A.V., Vostrukhov A.V., Vrouwenvelder A.C.W.M., Drag experienced by a high-speed train due to excitation of ground vibrations, International Journal of Solids and Structures, Vol. 38 (48), 2001, 8851-8868.

[3] Schillemans L., Impact of sound and vibration of the North-South high-speed railway connection through the city of Antwerp Belgium, Journal of Sound and Vibration, Vol. 267 (3), 2003, 637-649.

[4] PN-85/B-02170, Evaluation of the harmfulness of building vibrations due to ground motion (in Polish). 